\title{
Inovasi Pengembangan Kurikulum PAI di Sekolah Menengah Pertama Raudatut Tholabah Berbasis Pesantren
}

\author{
Mursalim ${ }^{1 *}$, Hatta ${ }^{2}$ \\ ${ }^{1}$ Fakultas Tarbiyah dan Ilmu Keguruan, IAIN Jember \\ 2 Fakultas Tarbiyah dan Ilmu Keguruan, IAIN Jember
}

Keywords:

Inovasi, Pengembangan Kurikulum PAI, Sekolah Berbasis Pesantren

*Correspondence Address:

salimabuya@gmail.com

\begin{abstract}
Innovation in the development of the Islamic Education curriculum is important because of the moral decline in various elements of society. This destructive if not responded quickly, precisely, and intelligently can have a negative impact. The purpose of this study is to describe the implementation of innovative curriculum development through curricular and extracurricular activities in pesantren-based Roudhatut Thalabah Middle School. This research is a qualitative method. Data collection uses observation, interview, and documentation techniques. Data analysis uses descriptive qualitative methods. Data validity uses the triangulation of sources and techniques. The results of this study at Tholabah Middle School innovated in developing the Islamic Education curriculum through curriculum integration and collaboration between schools and dormitories. As well as making PAI subjects, in general, a nomenclature of subjects in schools, but PAI learning was developed into a standalone subject in the form of the Al-Qur'an, Hadis, Fiqh, SKI, and Akidah Akhlak.
\end{abstract}

\section{PENDAHULUAN}

Pendidikan dan kurikulum adalah hal yang tidak bisa dipisahkan, ini karena kurikulum dengan pendidikan memiliki keterkaitan satu sama lain. Ini sejalan dengan para pakar pendidikan yang menyatakan bahwa fungsi utama sekolah adalah pembinaan dan pengembangan semua potensi individu, terutama pengembangan potensi fisik, intelektual, dan moral peserta didik.

Maka sekolah harus berfungsi sebagai tempat pendidikan formal untuk mengembangkan semua potensi peserta didik sebagai sumber daya manusia. Tujuan dari pendidikan ialah isi, bahan, metode, serta evaluasi dari hasil belajar yang dirancang menjadi suatu program kegiatan pendidikan

\footnotetext{
1 Hasan Baharun, Pengembangan Kurikulum, Teori dan Praktik, Karanganyar Paiton Probolinggo, (Pustaka Nurja 2017), 87
}

yang disebut kurikulum. Maka dalam rangka memenuhi fungsi itulah kurikulum perlu di susun dan diorganisir, dikembangkan agar sejalan dengan harapan dan fungsinya. ${ }^{1}$

Namun selama ini sekolah dianggap kurang atau bahkan gagal dalam membentuk akhlak dan karakter peserta didik, mata pelajaran PAI tidak bisa menjawab problem laten kebutuhan zaman dan masyarakat. Perilaku immoralitas peserta didik semakin menghawatirkan. Menurut Baedowi, sekolah belum berhasil membawakan perannya sebagai agen perubahan karakter. $^{2}$ Hal itu juga diamini oleh Muhaimin bahwa sekolah gagal menggarap sikap dan prilaku

\footnotetext{
2 Ahmad Baedowi, et.al., Potret Pendidikan Kita (Jakarta: Pustaka Alvabet, 2015), 313
} 
keberagamaan peserta didik.3 Indikatornya adalah ketidakjujuran dan tidak hormat anak kepada orang tua dan guru, Pacaran yang melampaui batas norma agama, meningkatnya tindak kekerasan di kalangan remaja, dan maraknya penggunaan narkoba serta alkohol di kalangan para remaja.

Kegagalan sekolah untuk membangun karakter dan moral anak bangsa melalui materi PAI menurut Mulyasa disebabkan beberapa faktor:4 (1) Islam diajarkan lebih pada hafalan, padahal Islam penuh dengan nilai-nilai (values) yang harus dipraktekkan; (2) pendidikan agama lebih ditekankan pada hubungan formalitas antara hamba dan Tuhannya; (3) penalaran dan argumentasi berfikir untuk masalah-masalah keagamaan kurang mendapat perhatian; (4) penghayatan nilai-nilai agama kurang mendapat penekanan; (5) menatap lingkungan untuk kemudian memasukkan nilai Islam sangat kurang mendapat perhatian; (6) metode pembelajaran agama, khususnya yang berkaitan dengan nilai-nilai Islam kurang mendapat penggarapan; (7) ukuran keberhasilan pendidikan agama juga masih formalitas termasuk verbalistis; (8) pendidikan agama belum mampu menjadi landasan kemajuan dan kesuksesan untuk mata pelajaran lain; (9) pendidikan agama belum dijadikan fondasi pendidikan karakter peserta didik dalam perilaku keseharian.

Menghadapi fenomena tersebut diperlukan jalan keluar yang baik dan segera dilakukan oleh berbagai pihak, baik di lingkungan keluarga, sekolah, dan masyarakat agar hal-hal negatif

\footnotetext{
3 Muhaimin, Pemikiran dan Aktualisasi Pengembangan Pendidikan Islam (Jakarta: Rajawali Pers, 2012), 154

4 E. Mulyasa, "Meningkatkan Kualitas Pendidikan Agama Islam" dalam Abdul Majid dan Dian Andayani, Pendidikan Agama Islam Berbasis Kompetensi: Konsep
}

tersebut tidak dibiarkan berlarut-larut. ${ }^{5}$ Gagasan praksis inovasi pengembangan kurikulum PAI di sekolah dengan basis pesantren merupakan ikhtiar rasional untuk menemukan jalan keluar dari persoalan pelik dunia pendidikan. Kurikulum PAI di sekolah harus dikembangkan, pembelajaran PAI yang selama ini hanya tiga jam dan dipandang tidak cukup untuk menanamkan karakter peserta didik, harus dirubah. maka diperlukan inovasi kurikulum PAI yang bisa mengakomudir karakter intelektual, spritual dan ahlakul karimah.

Sekolah Menengah Pertama Raudatut Tholabah berbasis pesantren sudah melakukan Inovasi terhadap Pengembangan kurikulum pendidikan agama Islam dengan cara; Pertama, Mengubah nomenklatur pelajaran PAI di sekolah. Pada umumnya dalam kurikulum, pelajaran PAI terdiri dari beberapa rumpun keilmuan yang terpadu, namun di sekolah ini mata pelajaran PAI berupa mata pelajaran yang berdiri sendiri seperti kurikulum pelajaran agama di madrasah yakni: AlQur'an Hadits, SKI, Fiqih dan Aqidah Akhlak. Kedua, adanya integrasi kurikulum dengan mengkolaborasikan antara sekolah dengan pendidikan pesantren, misalnya pendidikan di sekolah tidak hanya menekankan pada pelajaran formal saja, akan tetapi juga ada pelajaran yang berkaitan dengan nilai-nilai keagamaan. Pengembangan kurikulum bukan hanya berpusat pada penyampaian materi saja, akan tetapi kurikulum yang dimaksudkan dapat menghasilkan perubahan belajar.

dan Implementasi Kurikulum 2004 (Bandung: PT. Remaja Rosdakarya, 2004), iv

5 Tim Dosen PAI, Bunga Rampai Penelitian dalam Pendidikan Agama Islam (Yogyakarta: Deepublish, 2016), 171 
Inovasi pengembangan kurikulum PAI yang ada di SMP Raudatut Tholabah berbasis pesantren dilakukan untuk menjawab berbagai fenomena kegagalan lembaga pendidikan dalam menanamkan karakter dan akhlakul karimah bagi siswanya. Pengembangan kurikulum dirancang untuk memenuhi kebutuhan siswa, akan tetapi tidak merubah tatanan yang telah ditentukan oleh pemerintah

Berdasarkan hal di atas, maka penelitian ini difokuskan pada pelaksanaan inovasi pengembangan kurikulum PAI melalui kurikuler dan ekstrakurikuler di sekolah menengah pertama Roudhatut Thalabah.

\section{KAJIAN TEORI}

\section{Pengertian Kurikulum PAI}

Kata Kurikulum memiliki banyak arti yang berbeda tergantung dari posisi seseorang dalam sistem pendidikan. Sebagai contoh, seorang pembuat kurikulum akan melihatnya sebagai suatu rencana untuk pengalaman kurikulum di sekolah (yang ideal). Seorang guru akan melihatnya sebagai pemerintah atau orang yang biasanya berada di ruang kelas yang mengatakan padanya untuk mengajar (mempraktekkan), seorang siswa akan melihatnya sebagai apa yang harus saya pelajari untuk lulus sekolah atau madrasah (kenyataan), dan orang tua melihatnya sebagai apa yang sebenarnya telah di pelajari oleh anak saya di sekolah (prestasi). Pihak lain mungkin akan melihatnya sebagai buku atau materi untuk guru dan siswa.

Istilah kurikulum di gunakan pertama kali pada dunia olahraga pada zaman Yunani Kuno yang berasal dari kata curir dan curere, yang artinya jarak yang harus di tempuh oleh seorang atlit.

6 Hanun Asrohah, Buku Ajar Pengembangan Kurikulum, (Surabaya: Kopertais IV Press, 2012), 25
Istilah kurikulum kemudian di gunakan dalam dunia pendidikan. Dalam dunia pendidikan, para ahli memiliki pandangan yang beragam tentang kurikulum. Pengertin kurikulum berkembang sejalan dengan perkembangan pendidikan. Dalam pandangan lama, kurikulum di pandang sebagai kumpulan mata pelajaran yang harus di sampaikan oleh guru atau di pelajari oleh siswa. Pelajaran-pelajaran dan materi apa yang harus di tempuh sekolah, itulah kurikulum. ${ }^{6}$

\section{Inovasi Pengembangan Kurikulum}

Pengembangan kurikulum PAI sangat perlu dilakukan secara terusmenerus merespon perkembangan zaman. Masyarakat saat ini sudah memasuki era globalisasi baik dalam pendidikian maupun ilmu pengetahuan. Banyaknya masalah pendidikan harus segera diatasi tanpa harus menunggu keputusan dari dari pemangku kebijakan pendidikan yaitu Kemendikbud dan kementrian agama. Dalam pengembangan kurikulum, sekolah harus memiliki landasan yang kuat agar kurikulum memiliki nilai guna bagi masyarakat. Menurut Abdul Majid dan Dian andayani yang dikemukakan oleh Murray Print mengatakan bahwa landasan kurikulum terdiri dari landasan filosofi, sosial budaya, dan psikologi. Perkembangan ilmu dan teknologi menlengkapi landasan tersebut dengan lndasan manajemen. ${ }^{7}$

Pengembangan Kurikulum adalah istilah yang komprehensif, di dalamnya mencakup perencanaan, penerapan dan evaluasi. Pertama, perencanaan Kurikulum adalah langkah awal membangun kurikulum ketika pekerja kurikulum membuat keputusan dan mengambil tindakan untuk

\footnotetext{
${ }^{7}$ Majid dan Andayani, Pendidikan Agama Islam, 56-63.
} 
menghasilkan perencanaan yang akan di gunakan oleh guru dan peserta didik; Kedua, penerapan kurikulum atau biasa disebut implementasi kurikulum berusaha mentransfer perencanaan kurikulum ke dalam tindakan operasional; Ketiga, Evaluasi Kurikulum merupakan tahap akhir pengembangan kurikulum untuk menentukan seberapa besar hasil-hasil pembelajaran, tingkat ketercapaian program-program yang telah di rencanakan, dan hasil-hasil kurikulum, tidak hanya melibatkan orang yang terkait langsung dengan dunia pendidikan saja namun di dalamnya melibatkan banyak orang. ${ }^{8}$ Inovasi kurikulum dan pembelajaran dapat diartikan sebagai suatu ide, gagasan atau tindakantindakan tertentu dalam bidang kurikulum dan pembelajaran yang dianggap baru untuk memecahkan masalah pendidikan. Dalam bidang pendidikan, inovasi biasanya muncul dari adanya keresahan pihak-pihak tertentu tentang penyelenggaraan pendidikan. Misalnya, keresahan guru tentang pelaksanaan proses belajarmengajar yang dianggap kurang berhasil. Upaya untuk memecahkan masalah tersebut muncul gagasan dan ide-ide baru sebagai suatu inovasi. Pada hakikatnya pengembangan kurikulum merupakan pengembangan komponenkomponen kurikulum yang membentuk sistem kurikulum itu sendiri yaitu komponen tujuan, bahan, metode, peserta didik, pendidik, media, lingkungan, sumber belajar, dan lainlain. Komponen-komponen kurikulum tersebut harus dikembangkan, agar tujuan pendidikan dapat dicapai sebagaimana mestinya.

8 Muhaimin, Pengembangan Kurikulum Pendidikan Agama Islam di Sekolah, Madrasah, dan Perguruan Tinggi, (Jakarta : PT Raja Grafindo Persada, 2007)
Sebelum mengembangkan kurikulum hendaknya diadakan penilaian tentang kurikulum yang sedang dijalankan, hal ini dimaksudkan untuk mengetahui tingkat ketercapaian tujuan-tujuan yang tercantum dalam kurikulum tersebut. Dalam menilai kurikulum harus menilai komponenkomponennya, yaitu: (1) tujuan kurikulum, (2) pengalamanpengalaman belajar untuk mengembangkan pengetahuan, sikap dan keterampilan murid, (3) organisasi pengalaman belajar, urutan pengalaman dan hubungannya dengan pengalaman lain, (4) cara-cara mengevaluasi hasil belajar murid. ${ }^{9}$

\section{Kedudukan Kurikulum PAI di Sekolah}

Didalam UU Sisdiknas No 20 Tahun 2003, pasal 36 ayat 1 bahwa "Pengembangan kurikulum dilakukan dengan mengacu standar nasional pendidikan untuk mewujudkan tujuan pendidikan Nasional". ${ }^{10}$ Seiring dengan pemberlakuan otonomi daerah, yang berpengaruh juga pada pemberian otonomi pendidikan, menuntut adanya pengembangan kurikulum yang lebih akomodatif di sekolah.

Oleh karena itu, setiap satuan pendidikan Islam dituntut untuk mampu mengembangkan kurikulum, selain mengacu pada standar nasional pendidikan, juga harus mengacu pada keragaman kultur, dan potensi lingkungan daerah, sebagai bentuk pengembangan kurikulum muatan lokal, yakni menggali dan memberdayakan keragaman kultur dan potensi daerah sebagai bagian dari pengembangan kurikulum pendidikan. Dengan mengorientasikan pada

\footnotetext{
9 Oemar Hamalik, Dasar-Dasar Pengembangan Kurikulum, (Bandung: Rosda Karya, 2011)

10 UU Sisdiknas No 20 Tahun 2003 Tentang Sistem Pendidikan Nasional, 15
} 
peningkatan keimanan dan ketakwaan sebagai pemandu dalam menggali ilmu pengetahuan dan teknologi untuk menggali dan memberdayakan keragaman kultur dan potensi daerah, akan tampil sosok yang berketrampilan dan berakhlak mulia dalam rangka memenuhi tuntutan dunia kerja.

Sedangkan dalam Dalam UU Sisdiknas pasal 36 ayat 3, bahwa "Kurikulum disusun sesuai dengan jenjang pendidikan dalam kerangka Negara Kesatuan Republik Indonesia dengan memperhatikan peningkatan iman dan takwa, peningkatan akhlak mulia, peningkatan potensi, kecerdasan,dan minat peserta didik". ${ }^{11}$ Dari penggalan isi UU sisdiknas tersebut bahwa kurikulum khususnya kurikulum PAI telah terdapat didalam UU Sisdiknas No 20 tahun 2003. Pasal 37 ayat 1 poin a, "bahwa setiap kurikulum pendidikan wajib membuat pendidikan agama". ${ }^{12}$ Oleh sebab itu setiap lembaga pendidikan didalam kurikulumnya wajib mencantumkan pendidikan Agama. Hal tersebut karena mengacu pada UU Sisdiknas No 20 tahun 2003.

Pendidikan Agama di maksudkan untuk meningkatkan potensi spiritual dan membentuk peserta didik agar menjadi manusia yang beriman dan bertakwa kepada Tuhan Yang Maha Esa dan berakhlak mulia. Akhlak mulia mencakup etika, budi pekerti, dan moral sebagai perwujudan dari Pendidikan Agama. Peningkatan potensi spiritual mencakup pengalaman, pemahaman, dan penanaman nilai-nilai keagamaan, serta pengalaman nilai-nilai tersebut

11 Ibid.

12 Ibid.

13 Hanun Asrohah, Buku Ajar Pengembangan Kurikulum, 27

14 Sekolah Berbasis Pesantren (SBP) secara nasional mulai dideklarasikan tahun 2008 silam dengan jumlah anggota 25 SBP dan pada akhir tahun 2015 tercatat berkembang menjadi 302 SBP. Lihat Laporan dalam kehidupan individual ataupun kolektif kemasyarakatan. Peningkatan potensi spiritual tersebut pada akhirnya bertujuan pada optimalisasi berbagai potensi yang di miliki manusia yang aktualisasinya mencerminkan harkat dan martabatnya sebagai makhluk Tuhan. Manusia seperti itu yang di harapkan tangguh dalam menghadapi tantangan, hambatan dan perubahan yang muncul dalam pergaulan masyarakat baik dalam lingkup lokal, nasional, regional maupun global. ${ }^{13}$

\section{Sekolah Berbasis Pesantren}

Sekolah Berbasis Pesantren yang sering disingkat dengan $\mathrm{SBP},{ }^{14}$ adalah sekolah yang mengimplementasikan keterpaduan antara konsep pendidikan nasional dengan nilai-nilai ajaran Agama Islam (Pesantren). Konsep operasional Sekolah berbasis pesantren merupakan akumulasi dari proses pembudayaan, pewarisan dan pengembangan ajaran agama Islam, budaya dan peradaban Islam dari generasi ke generasi. Sekolah berbasis pesantren adalah sekolah yang mengintegrasikan kebenaran nash (AlQuran dan Hadis) dengan Sains (Ilmu Pengetahuan dan Teknologi) melalui pengembangan tiga dimensi pendidikan unggul, yaitu memiliki landasan moralitas keagamaan yang kuat, penguasaan ilmu pengetahuan dan teknologi, serta memiliki dan menguasai bentuk-bentuk keterampilan-keterampilan bekerja yang akan menunjang kehidupannya setelah selesai mengikuti pendidikan. ${ }^{15}$

\footnotetext{
Monitoring dan Evaluasi Program Sekolah Berbasis Pesantren, 7

15 Kementerian Pendidikan dan Kebudayaan RI, Direktorat Jenderal Pendidikan Dasar dan Menengah, Direktorat Pembinaan SMP, Laporan Monitoring dan EvaluasiProgram Sekolah Berbasis Pesantren (Jakarta: Dikdasmen, 2016), 4.
} 
Dinamika pesantren semakin adaptif dengan perkembangan zaman dengan menyelenggarakan sekolah berbasis pesantren, menjadikan pesantren memiliki peluang sebagai lembaga pendidikan Islam yang akan menciptakan manusia seutuhnya, dan membentuk masyarakat madani yang bercirikan masyarakat religius, demokratis, egalitarian, toleran, berkeadilan, dan berilmu. ${ }^{16}$ Pada tataran implementasinya, sekolah berbasis pesantren (SBP) merupakan model pendidikan unggulan yang mengintegrasikan pelaksanaan sistem persekolahan yang menitik beratkan pada pengembangan kemampuan sains dan keterampilan dengan pelaksanaan sistem pesantren yang menitik beratkan pada pengembangan sikap dan praktik keagamaan, peningkatan moralitas dan kemandirian dalam hidup. Perubahan sosial ini mengacu pada perubahan sistem sosial dan budaya yang memadukan sistem pendidikan sekolah dan sistem pendidikan pesantren, sehingga meluluskan ilmuwan yang agamawan.

Inovasi Pengintegrasian tersebut perlu dilakukan karena sistem pendidikan pesantren dan sistem sekolah masing-masing memiliki keunggulan dan kekurangan. Keunggulan pendidikan dipesantren antara lain: (1) Kegiatan siswa dipantau 24 jam. (2) Lebih banyak pendidikan agamanya. (3) Memiliki jiwa sosial tinggi. (4) Kegiatan Ekstrakurikuler lebih banyak. (5) Mandiri dan disiplin. Sedangkan keunggulan sistem sekolah umum adalah: (1) Pelajaran umum lebih banyak. (2) Memiliki kurikulum tetap dan lebih sistematis. (3) Banyak menggunakan metode pengajaran. ${ }^{17}$

16 Haidar Putra Daulay, Pendidikan Islam, dalam Sistem Pendidikan Nasional Indonesia (Jakarta: Kencana, 2004), 36.
Maka dengan terintegrasinya atau terpadunya keunggulan dari lembaga pesantren dan sekolah maka kekurangan dari masing-masing lembaga tersebut secara otomatis akan bisa diatasi. Misal Pelajaran agama di sekolah umum porsi waktunya sedikit (hanya 3 jam pelajaran per minggu), maka dengan konsep terpadu pembelajaran agama dapat berlangsung lebih lama dan praktiknya lebih nyata. Begitu pun dengan pondok pesantren, jika sebelumnya mata pelajaran umum waktunya belum memadai, sekarang porsi waktunya tersedia lebih cukup. Kini kedua disiplin keilmuan itu dapat berjalan sejajar dan sama-sama kuat.

Dengan pendekatan ini, semua mata pelajaran dan semua kegiatan sekolah tidak lepas dari bingkai ajaran dan pesan nilai Islam. Tidak ada dikotomi, tidak ada keterpisahan, semua bahasan tidak terlepas dari nilai dan ajaran Islam. Pelajaran umum, seperti matematika, IPA, IPS, bahasa, jasmani/kesehatan, keterampilan dibingkai dengan pijakan, pedoman dan panduan Islam. Sementara dalam pemahaman ilmu agama Islam, sekolah berbasis pesantren diperkaya dengan adanya kurikulum kepesantrenan yang khas ala pondok pesantren.

Dalam pemahaman yang sama hasil yang diharapkan dari sekolah berbasis pesantren ini, yaitu terwujudnya pendidikan yang integratif dan komprehensif bagi peningkatan mutu sumber daya manusiaIndonesia yang unggul; terwujudnya pendidikan yang berorientasi pada pengembangan keunggulan komparatif dan kompetitif dalam menghadapi persaingan global; tercapainya peningkatan mutu sumber daya manusia yang memiliki

17https://lalaleigha.wordpress.com/2017/02/01/se kolah-umum-vs-pesantren-mana-yang-lebih-baik/ 
kemampuan ganda. Dalam hal ini, outcome yang memiliki keseimbangan intelektual quotient, emotional quotient dan spiritual quotient. Selain itu, sekolah berbasis pesantren diarahkan agar terbentuknya sumber daya manusia Indonesia yang berwatak plural, nasional dan multikultural.

\section{METODE PENELITIAN}

Penelitian ini menggunakan pendekatan kualitatif yaitu pendekatan penelitian yang berusaha mendeskripsikan suatu gejala, peristiwa, dan kejadian yang terjadi saat ini. Adapun jenis penelitian yang digunakan adalah studi kasus. Dalam penelitian ini, peneliti akan memberikan gambaran secara kualitatif terhadap inovasi pengembangan kurikulum PAI di SMP Raudhatut Tholabah berbasis pesantren di Kemuningsari Jember. Sedangkan Teknik pengumpulan data dilakukan melalui wawancara, observasi, dan dokumentasi. Teknik analisis data menggunakan konsepnya Sugiyono, yaitu reduksi data, penyajian data, dan kesimpulan. ${ }^{18}$

\section{HASIL DAN PEMBAHASAN}

Dalam pelaksanaannya inovasi pengembangan kurikulum PAI di SMP Raudahatut Tholabah berbasis pesantren dilakukan dengan dua cara:

\section{Inovasi pengembangan kurikulum PAI Melalui Kurikuler}

Inovasi pengembangan kurikulum PAI melalui kurikuler ini lebih cenderung pada pengertian yang dikemukakan Zahrana bahwa Pengembangan kurikulum pendidikan agama Islam (PAI) dapat diartikan

\footnotetext{
18 Sugiyono, Metode Penelitian Kuantitatif Kualitatif (Bandung: Alfabeta, 2010), 246-252
}

sebagai: (1). kegiatan menghasilkan kurikulum PAI (2) proses yang mengkaitkan satu komponen dengan yang lainnya untuk menghasilkan kurikulum PAI yang lebih baik (3) kegiatan penyusunan (desain), pelaksanaaan, penilaian dan penyempurnaan kurikulum PAI. ${ }^{19}$

Dari landasan inilah maka SMP Raudatut Tholabah melakukan inovasi pengembangan kurikulum pendidikan agama Islam (PAI) dengan dua cara:

Pertama; membagi mata pelajaran PAI menjadi lima mata pelajaran yaitu : Fiqih, al-Qur'an Hadits, Sejarah Kebudayaan Islam dan Aqidah Akhlak. Hal ini dilakukan untuk menutupi kekurangan materi mata pelajaran PAI, mata pelajaran PAI yang hanya diajarkan dua jam di sekolah belum bisa menjawab tujuan pendidikan. Sehingga siswa belum memiliki karakter dan akhlakul karimah. Hal itulah yang mendorong Mutamakkin Abdullah bersama komite sekolah melakukan inovasi kurikulum di SMP Raudatut Tholabah dengan mengubah mata pelajaran pendidikan agama Islam disekolah dengan rumpun mata pelajaran Fiqih, al-Quran Hadits, Sejarah Kebudayaan Islam dan Aqidah Akhlak. Dalam pelaksanaannya kurikulum PAI ini tetap mengikuti ketetapan pemerintah, walau ada yang ditambahi oleh sekolah sendiri, sehingga ciri khas kurikulum PAI di Sekolah ini sama dengan kurikulum di Madrasah. ${ }^{20}$

\section{Kedua;}

pengintegrasian kurikulum sekolah dengan pesantren. Pengintegrasian ini dilakukan dengan memasukkan pelajaran kitab Aqidatul Awam, Fathul Qorib, Akhlakul Banin dan ilmu Quran kedalam kurikulum

\footnotetext{
19https://zahranaa.blogspot.com/2017/08/pengem bangan-kurikulum-pai.html

20 Mutamakkin Abdullah, wawancara, 2019
} 
sekolah, jadi pembelajarannya dilakukan pada waktu sekolah dan seluruh siswa dan siswi wajib ikut. hal ini dilakukan karena sistem pendidikan sekolah dan sistem pesantren masingmasing memiliki keunggulan dan kekurangan. ${ }^{21}$

Keunggulan pendidikan di pesantren antara lain: (1) Kegiatan siswa dipantau 24 jam. (2) Lebih banyak pendidikan agamanya. 3) Memiliki jiwa sosial tinggi. (3) Kegiatan Ekstrakurikuler lebih banyak. (4) Mandiri dan disiplin. Sedangkan keunggulan sistem sekolah umum adalah: (1) Pelajaran umum lebih banyak. (2) Memiliki kurikulum tetap dan lebih sistematis. (3) Banyak menggunakan metode pengajaran. ${ }^{22}$

Maka dengan terintegrasinya keunggulan dari lembaga pesantren dan sekolah maka kekurangan dari masingmasing lembaga tersebut secara otomatis akan bisa diatasi. Misal pelajaran agama di sekolah umum porsi waktunya sedikit (hanya tiga jam pelajaran per minggu), maka dengan adanya kajian kitab-kitab fiqih, tauhid, akhlak dan al-Quran maka dapat ditutupi dan praktiknya lebih nyata. Begitu pun dengan pondok pesantren, jika sebelumnya mata pelajaran umum waktunya belum memadai, sekarang porsi waktunya tersedia lebih cukup. Kini kedua disiplin keilmuan itu dapat berjalan sejajar dan sama-sama kuat.

Dengan pendekatan ini, semua mata pelajaran dan semua kegiatan di SMP Raudatut Tholabah tidak lepas dari bingkai ajaran dan pesan nilai Islam. Tidak ada dikotomi, tidak ada keterpisahan, semua bahasan tidak terlepas dari nilai dan ajaran Islam. Pelajaran umum, seperti matematika,

21 Mutamakkin Abdullah, wawancara, 2019

22https://lalaleigha.wordpress.com/2017/02/01/se kolah-umum-vs-pesantren-mana-yang-lebih-baik/ ${ }^{23}$ Mutamakkin Abdullah, wawancara, 2019
IPA, IPS, bahasa, jasmani/kesehatan, keterampilan dibingkai dengan pijakan, pedoman dan panduan Islam. Sementara dalam pemahaman ilmu agama Islam, sekolah berbasis pesantren diperkaya dengan adanya kurikulum kepesantrenan. Kurikulum yang khas ala pondok pesantren. ${ }^{23}$

\section{Inovasi Pengembangan Kurikulum PAI Melalui Ektrakurikuler}

Pelaksanaan inovasi

pengembangan kurikulum PAI Melalui ekstrakurikuler di SMP Raudatut Tholabah dilakukan dengan beberapa kegiatan sebagai berikut:

\section{Doa Bersama dan Membaca Al- Qur'an}

Sebelum proses kegiatan belajar mengajar dimulai didalam kelas, seluruh pendidik dan tenaga kependidikan mengadakan doa bersama dan membaca al-Qur'an setiap pagi bertempat di Masjid. Hal ini diharapkan agar siswa dan semua tenaga kependidikan terbiasa mengawali harinya untuk berbagai kegiatan apapun dengan berdoa mengharap ridho Allah SWT.

Selain berdoa juga membaca alQur'an merupakan bentuk peribadatan yang diyakini dapat mendekatkan diri kepada Allah SWT. dapat meningkatkan keimanan dan ketaqwaan yang berimplikasi pada sikap dan perilaku yang positif, dapat mengontrol diri, mendapat ketenangan, lisan terjaga dan istiqomah dalam beribadah. Melalui kegiatan membaca al-Qur'an para siswa dapat tumbuh sikap-sikap luhur sehingga berpengaruh terhadap peningkatan prestasi belajar dan juga dapat membentangi diri dari pengaruh negative. ${ }^{24}$

24 Asmaun Sahlan, Mewujudkan Budaya Religius di Sekolah (Upaya Mengembangkan PAI dari Teori ke Aksi), (Malang: UIN-Maliki Press, 2009), 120. 
Selain itu, Untuk hari Jum'at doa bersama dan membaca al-Qur'an diganti dengan kegiatan istighosah dan lain-lain, istighosah adalah doa bersama yang bertujuan memohon pertolongan Allah SWT. inti dari kegiatan istighosah ini sebenarnya dzikrullah dalam rangka taqqaub ila Allah (mendekatkan diri kepada Allah SWT) serta untuk memperkaya dan menambah wawasan pengetahuan agama siswa melalui amalan-amalan sunnah yang dapat menambah tabungan amal kebaikan, karena amalan-amalan sunnah merupakan anjuran untuk dikerjakan dan merupakan amalan yang baik yang dapat menghapus amalan yang buruk pada seseorang manusia, disebabkan manusia tidaklah luput dari tindakan salah. ${ }^{25}$

Selanjutnya amalan sunnah juga menyempurnakan kekurangan pada ibadah wajib yang mungkin terlewatkan oleh manusia. Jika manusia sebagai hamba selalu dekat dengan sang Khaliq, maka segala keingginannya akan dikabulkan oleh-Nya. Istighosah ini sudah membudaya, hal ini karena memberikan pengaruh luar biasa pada mentalitas warga madrasah. ${ }^{26}$

\section{Shalat Dhuha Berjama'ah}

Shalat Dhuha adalah shalat sunah yang dilakukan setelah terbit matahari sampai menjelang masuk waktu zhuhur. Afdhalnya dilakukan pada pagi hari disaat matahari sedang naik (kira-kira jam 9.00 WIB). Shalat Dhuha merupakan shalat sunnah, shalat yang apabila di kerjakan mendapatkan pahala dan apabila tidak di kerjakan tidak mendapatkan dosa.

Adapun bilangan rakaat shalat Dhuha sekurang-kurangnya adalah dua rakaat dan sebanyak-banyaknya tidak

\footnotetext{
25 Mutamakkin Abdullah, wawancara, 2019

26 Muhammad Jazuli, wawancara, 2019
}

ada batasan. Inilah yang dirajihkan oleh Syekh Ibnu Utsaimin dalam pernyataan beliau, Yang benar adalah bahwasanya tidak ada batas untuk banyaknya, karena 'Aisyah berkata: Rasulullah shallallahu 'alaihi wa sallam dahulu melakukan shalat Dhuha sebanyak empat rakaat, dan beliau menambahnya sebanyak yang beliau inginkan. ${ }^{27}$

Jumlah rakaat shalat Dhuha tidak ada pembatasannya. Seandainya seorang shalat dari terbit matahari setombak sampai menjelang tergelincir matahari, misalnya empat puluh rakaat, maka ini semua masuk dalam shalat Dhuha. Pelaksanaan program ekstrakurikuler keagamaan shalat Dhuha di SMP Raudatut Tholabah dikerjakan rutin setiap harinya 4 rakaat dan mengucapkan salam setiap 2 rakaat, karena pada rakaat shalat Dhuha tidak ada batasannya mengambil inisiatif untuk mengerjakan 4 rakaat berkenaan dengan waktu proses pembelajaran dikelas yang dilaksanakan setelah mengerjakan shalat Dhuha. ${ }^{28}$

Bacaan surat shalat Dhuha tidak ada keterangan dari Rasulullah mengenai surat tertentu yang harus dibaca ketika shalat Dhuha. Kita dipersilahkan membaca surat apa pun sesuai dengan kemampuan dan keinginan kita. Kita pun diperkenankan untuk membaca surat Adh-Dhuha, AsySyams, atau surat-surat lain yang menjadi favorit atau pilihan, namun ada anjuran bacaan surat yang wajib dihafal untuk dibaca ketika melaksanakan shalat Dhuha yaitu surat Asy-Syam dan Adh-Dhuha.

Tidak salah jika kita membaca surat Adh-Dhuha di dalam salah satu rakaat shalat Dhuha. Sebab, banyak nilai-nilai moral dan spiritual yang

\footnotetext{
${ }^{27}$ HR. Muslim, Kitab Shalat al-Musafirin wa Qashruha, Bab Istihbaab Shalat Dhuha, no. 719

${ }^{28}$ Mutamakkin Abdullah, wawancara, 2019
} 
terkandung di dalamnya. Harapanya, kita dapat memahami dan menghayatinya. Lalu, menjadikanya bekal untuk memulai aktivitas. Namun pada pelaksanaannya secara pribadi tidak mewajibkan untuk membaca kedua surat tadi para siswa bebas membaca surat yang dihafalnya atau yang disukainya.

Beberapa doa yang dibaca setelah shalat Dhuha yaitu shalawat nariyah, shalawat tibh al qulub dan shalawat fatih. Dengan membaca shalawat nariyah bertujuan untuk Terlepas dari segala kesulitan (dimudahkan rezekinya), terhindar dari bencana, semua keinginan dikabulkan, kebutuhan bisa terpenuhi dan lain-lain. Shalawat Tibh al-Qulub ini bila diamalkan secara istiqomah (ajeg, terus menerus) insyaAllah akan diselamatkan dari berbagai macam penyakit, baik penyakit lahiriah maupun batiniah. Tentu saja disamping itu juga terdapat manfaat-manfaat yang lain, sebagaimana keterangan dari banyak hadist Nabi SAW yang menerangkan keutamaan dari membaca shalawat akan memberikan berbagai macam kebaikan dan manfaat. ${ }^{29}$

Selanjutnya adalah Shalawat Fatih, Shalawat ini dikarang oleh Syech Sayyid Muhammad Syamsuddin ibn Abil Hasan al Bakri RA, adapun gunanya adalah: Untuk menghilangkan pikiran yang resah atau susah. Barang siapa membaca shalawat al Fatih tersebut, seumur hidup sekali saja Insya Allah diselamatkan dari api neraka. Shalawat Nariyah, Shalawat Tibh al Qulub dan Shalawat Fatih dijadikan sebagai doa setelah shalat Dhuha dengan motivasi agar dalam menempuh pendidikan dimudahkan oleh Allah SWT. ${ }^{30}$
Hal ini bertujuan untuk membentuk moral atau akhlak seluruh warga sekolah khususnya para siswanya dengan baik, menginggat karena begitu besar manfaatnya bagi pribadi yang menjalankan shalat Dhuha ini. Beberapa manfaat yang diharapkan dapat membentuk moralitas keagamaan bagi siswa yaitu: ${ }^{31}$

Pertama, shalat Dhuha dapat meningkatkan kecerdasan fisikal, kecerdasan emosional spiritual dan kecerdasan intelektual.

Untuk kecerdasan fisikal, shalat Dhuha mampu meningkatkan kekebalan tubuh dan kebugaran fisik. Shalat Dhuha merupakan alternative olahraga yang efektif dan efisien karena dilakukan pada pagi hari ketika sinar matahari pagi masih baik untuk kesehatan dan kondisi udara yang bersih. Penelitian mutakhir menjelaskan bahwa bukan olahraga berat dan mahal yang efektif untuk menjaga kebugaran tubuh. Namun, olahraga ringan dan tidak beresiko cedera serta dilakukan dengan senang hati yang terbukti mampu menjaga kebugaran tubuh.

Di sini, SMP Raudatut Tholabah memilih shalat Dhuha tentunya sebagai olahraga yang paling cocok. Untuk kecerdasan emosional spiritual, melaksanakan shalat Dhuha pada pagi hari sebelum beraktivitas, selain berbekal optimisme, tawakal, serta pasrah atas segala ketentuan dan takdir Allah, dapat menghindarkan diri dari berkeluh-kesah dan kecewa karena kegagalan yang dialami.

Untuk kecerdasan intelektual hal ini berkaitan sekali dengan pribadi siswa yakni memiliki tanggungjawab belajar, dengan shalat Dhuha diharapkan proses belajar mengajar 
berjalan dengan baik, menjadikan pikiran lebih konsentrasi sehingga dimudahkan masuknya ilmu yang bermanfaat.

Kedua, shalat Dhuha dapat melancarkan rizki

Pelaksanaan shalat Dhuha di SMP Raudatut Tholabah ini bertujuan untuk membentuk moral siswanya agar senantiasa tidak melupakan doa dan bertawakal kepada Allah SWT. setelah usaha atau bekerja yang sungguhsungguh. Kerja tanpa do'a adalah kesombongan dan "kekufuran" karena tidak "butuh" restu dan pertolongan dari sang maha pemilik rezeki. Do'a tanpa usaha adalah sia-sia atau omong kosong. Sedangkan tawakal adalah kepasrahan hati menerima segala ketentuan Allah satelah usaha dan do'a dilakukan. Jika berhasil, bersyukurlah. Tetapi, jika tidak berhasil, jangan bersedih dan putus asa. Yang harus dilakukan jika apa yang diinginkan tidak tercapai adalah mengevaluasi apa yang kurang dari usaha dan do'a kita. Salah satu hikmah diisyaratkanya shalat Dhuha adalah jalan kemudahan usaha dan kelapangan rezeki yang diberikan Allah kepada hamba-Nya yang shaleh.

Menurut Muhammad Yasin, shalat Dhuha berjama'ah ini bertujuan agar para siswa tidak hanya melaksanakan amalan/ibadah wajib saja namun mengajarkan dan membiasakan mengerjakan amalan-amalan sunnah. Hal ini bertujuan pula untuk mengharap rizqi dari Allah karena rizki tidak hanya berupa harta saja namun dalam berbagai aspek termasuk rizqi memperoleh ilmu pengetahuan yang barakah manfaat didunia dan akhirat. Hal ini merupakan pelatihan bentuk ibadah perorangan atau jama'ah yang bertujuan untuk menjadikan peserta

32 Muhammad Jazuli, wawancara, 2019

${ }^{33}$ Agus Lukman Hakim, wawancara, 2019 didik sebagai muslim yang disamping berilmu juga mampu mengamalkan ajaran agamanya dalam kehidupan sehari-hari. ${ }^{32}$

Shalat Dhuha ini dapat membentuk karakter moral yang baik bagi siswa yaitu tanggung jawab pribadi pada Tuhan terhadap amalan-amalan Sunnah yang dilakukan. Menurut beberapa tanggapan dari para siswanya mereka sangat antusias dan dengan rutin melaksanakan shalat Dhuha bukan hanya pada lingkungan sekolah namun pada kehidupan sehari-hari mereka diluar sekolah. Pemahaman hikmah amalan tersebut dijadikan sebagai motivasi (targhib) untuk melaksanakan amanalan tersebut guna membangun diri menjadi lebih baik dan sebagai pendorong agar kita giat beribadah. ${ }^{33}$

\section{Shalat Dhuhur Berjama'ah}

Pembiasaan merupakan upaya yang sangat penting dilakukan dalam hal pembinaan dan pembentukan kepribadian seseorang. Kebiasaan adalah sebuah tindakan atau perbuatan seseorang yang dilakukan secara berulang-ulang dalam bentuk yang sama sehingga menjadi kebiasaan. Langkah selanjutnya yang dilakukan oleh SMP Raudatut Tholabah adalah membiasakan siswa untuk disiplin melaksanakan shalat berjama'ah. ${ }^{34}$

Shalat dalam bahasa Arab berarti Do'a, sedangkan yang di maksud shalat disini adalah ibadah yang tersusun dari beberapa perkataan dan perbuatan yang dimulai dengan takbir, dan di sudahi dengan salam. Shalat Dhuhur dilaksanakan secara berjama'ah oleh seluruh warga madrasah agar tercipta kebersamaan dan kekeluargaan. Diketahui bahwasanya ibadah shalat lebih utama dilaksanakan secara berjama'ah dan pahala yang didapatkan

34 Muhammad Yusuf, wawancara, 2019 
juga lebih banyak dibandingkan dengan shalat sendiri.

Motivasi menjalankan shalat Dhuhur berjamaah ini selain begitu besar manfaat dan terdapat hikmah lain yang menyangkut beberapa aspek, baik aspek pendidikan, sosial maupun dari sisi balasan yang akan kita dapatkan (pahala). Pada aspek pendidikan, kita ambil contoh shalat berjama'ah yang mengajarkan akan sikap kedisiplinan. ${ }^{35}$

Hal ini bisa dilihat dari adanya kedisiplinan waktu dalam melaksanakannya. Ketika adzan berkumandang, praktis para warga madrasah yang melakukan shalat berjamaah akan bergegas menuju masjid pada waktu itu juga. Disamping itu, shalat yang dilaksanakan secara berjamaah juga mendidik kita untuk menghilangkan sikap egoisme, sebab kita tidak mungkin mengikuti kemuauan kita untuk ruku' mendahului imam atau melakukan salam lebih dini. Akan tetapi kita dituntut taat mengikuti gerak gerik seorang imam.

Dengan demikian, semakin kita sering shalat berjamaah maka semakin terdidik diri kita untuk mengendalikan atau melunakan sikap egoisme pada diri kita. Dari aspek sosial, shalat berjama'ah merupakan manifestasi dari itihadul musim (bersatunya umat Islam). Tanpa adanya pecah belah diantara mereka. Tanpa memandang derajat antara kaya dan miskin. Bersatu padu dalam komando seorang imam. Disamping itu, ibadah shalat yang di lakuan secara jama'ah akan mencipatankan rasa empati terhadap sesama, hingga akhirnya tercipta sebuah rasa kasih sayang antar sesama muslim yang berawal dari ta'aruf. ${ }^{36}$

\footnotetext{
35 Mutamakkin Abdullah, wawancara, 2019
}

36 Muhammad Jazuli, wawancara, 2019

\section{Membaca Asmaul Husna}

Asmaul Husna adalah nama-nama Allah SWT yang baik, Asmaul Husna merupakan cerminan dari perilaku Allah SWT terhadap umatnya. Karena itu bila nama-nama itu kita sebut sebagai suatu pemohonan, maka akan mempunyai pengaruh yang sangat besar.

Menurut M. Yusuf, asmaul husna ini dibaca pada setiap hari kamis saja untuk lebih meningkatkan keimanan dan ketaqwaan para siswa, dan hal ini bertujuan mengarah pada kecakapan ubudiyah dan akhlakul karimah. Diharapkan pula para siswa-siswi dapat meneladani sikap-sikap seperti yang terkandung dalam asmaul husna. ${ }^{37}$

Dalam setiap asmaul husna mempunyai makna yang berbeda-beda, jika diamalkan secara rutin di sekolah diharapkan semoga mendapatkan manfaat dari setiap pelafalan asmaul husna terhadap semua warga sekolahhnya berkenaan dengan segala aktivitas pembelajaran di sekolah dan berkelanjutan pada aktivitas sehari-hari pada setiap pribadi untuk mengamalkannya. Kesungguhan dalam mengamalkan Asmaul Husna merupakan syarat yang mutlak diterimanya suatu permohonan, selain itu dibutuhkan juga keyakinan dan kesabaran yang penuh. ${ }^{38}$

\section{KESIMPULAN}

Pelaksanaan

inovasi pengembangan kurikulum PAI melalui kurekuler dilakukan dengan dua cara:

Pertama; membagi mata pelajaran PAI menjadi lima mata pelajaran Fiqih, al-Qur'an Hadits, Sejarah Kebudayaan Islam dan Aqidah Akhlak. Hal ini dilakukan untuk menutupi kekurangan materi mata pelajaran PAI, mata

\footnotetext{
37 Muhammad Yusuf, wawancara, 2019

38 Mutamakkin Abdullah, wawancara, 2019
} 
pelajaran PAI yang hanya diajarkan dua jam di sekolah belum bisa menjawab tujuan pendidikan. Sehingga siswa belum memiliki karakter dan akhlakul karimah. Untuk itulah kepala sekolah bersama komite sekolah melakukan inovasi pengembangan kurikulum PAI di SMP Raudatut Tholabah dengan mengubah mata pelajaran pendidikan agama Islam dengan lima rumpun mata pelajaran; Fiqih, al-Quran Hadits, SKI dan Aqidah Akhlak. Dalam pelaksanaannya kurikulum PAI ini tetap mengikuti ketetapan pemerintah, walau ada yang ditambahi oleh sekolah sendiri, sehingga ciri khas kurikulum PAI di Sekolah ini sama dengan kurikulum di Madrasah. Kedua;

pengintegrasian kurikulum sekolah dengan pesantren. Pengintegrasian ini dilakukan dengan memasukkan pelajaran kitab Aqidatul Awam, Fathul Qorib, Akhlakul Banin dan ilmu Quran kedalam kurikulum sekolah, jadi pembelajarannya dilakukan pada waktu sekolah dan seluruh siswa dan siswi wajib ikut. Dengan terintegrasinya kurikulum pesantren dan sekolah maka kekurangan dari masing-masing lembaga tersebut sedikit banyak bisa diatasi. Misal pelajaran agama di sekolah waktunya hanya tiga jam pelajaran per minggu, maka dengan adanya kajian kitab-kitab fiqih, tauhid, akhlak dan al-Quran maka dapat ditutupi. Begitu pun dengan pesantren, jika sebelumnya mata pelajaran umum waktunya belum memadai, sekarang porsi waktunya tersedia lebih cukup. Kini kedua disiplin keilmuan itu dapat berjalan sejajar dan sama-sama kuat.

Sedangkan inovasi pengembangan kurikulum PAI melalui ekstrakurikuler dilakukan dengan cara penguatan nilainilai keagaman melalui kegiatan doa bersama dan membaca Al-Qur'an, shalat Dhuha, shalat Dhuhur berjamaah, membaca asmaul husna. Kegiatan ekstrakurekuler ini dilakukan dilakukan diluar jam pelajaran, dimulai dengan kegiatan doa bersama, kemudian dilanjutkan denga shalat Dhuha berjamaah baru siswa-siswi masuk kedalam kelas, diparuh pembelajaran semua siswa menuju mesjid untuk shalat Dhuhur berjamaah.

\section{REFERENSI}

Baedowi, Ahmad, et.al., Potret Pendidikan Kita, Jakarta: Pustaka Alfabet, 2015

Baharun, Hasan, Pengembangan Kurikulum, Teori dan Praktik, Probolinggo:Pustaka Nurja, 2017

Daulay, Haidar Putra, Historisitas dan Eksistensi Pesantren dan Madrasah, Yogyakarta: Tiara Wacana, 2001

Daulay, Haidar Putra, Pendidikan Islam, dalam Sistem Pendidikan Nasional Indonesia, Jakarta: Kencana, 2004

Dhofier, Zamakhsyari, Tradisi Pesantren: Studi Tentang Pandangan Hidup Kiyai, Jakarta: LP3ES, 1981

Gugunel-Guyanie, Resolusi Jihad Paling Syar'I, Yogjakarta: Pustaka Pesantren, 2010

https://lalaleigha.wordpress.com/201 7/02/01/sekolah-umum-vspesantren-mana-yang-lebih-baik/ https://zahranaa.blogspot.com/2017/ 08/pengembangan-kurikulumpai.html

Kementerian Pendidikan dan Kebudayaan RI, Direktorat Jenderal Pendidikan Dasar dan Menengah, Direktorat Pembinaan SMP, Laporan Monitoring dan Evaluasi Program Sekolah Berbasis Pesantren, Jakarta: Dikdasmen, 2016 
Koentjaraningrat, Kebudayaan, Mentalitet dan Pembangunan, Jakarta: Gramedia, 1976.

Madjid, Nurcholis, Bilik-bilik Pesantren Jakarta: Paramadina, 1997

Majid, Abdul dan Dian Andayani, Pendidikan Agama Islam Berbasis Kompetensi: Konsep dan Implementasi Kurikulum 2004 Bandung: PT. Remaja Rosdakarya, 2004

Mastuhu, Sistem Pendidikan pesantren, Jakarta: INIS, 1994

Muhaimin, Pemikiran dan Aktualisasi Pengembangan Pendidikan Islam, Jakarta: Rajawali Pers, 2012

Mulyana, Dedi, Metodologi Penelitian Kualitatif, Bandung: Remaja Rosdakarya, 2006

Rahmat, PAI Interdisipliner: Layanan Khusus CIBI, Kenakalan Remaja, Integrasi IMTAQ dan IPTEK, Pendidikan Anti Kekerasan dan Kurikulum Berbasis Karakter Yogyakarta: Deepublish, 2016

Sahlan, Asmaun, Mewujudkan Budaya Religius di Sekolah; Upaya Mengembangkan PAI dari Teori ke Aksi, Malang: UIN-Maliki Press, 2009

Siradj, Said Aqil, Tasawuf sebagai Kritik Sosial: Mengedepankan Islam sebagai Inspirasi bukan Aspirasi, Bandung: Mizan, 2006

Sugiyono, Metode Penelitian Kuantitatif Kualitatif, Bandung: Alfabeta, 2010

Tim Departemen Agama RI, Pola Pengembangan Pondok Pesantren, Jakarta: Direktorat Jenderal Kelembagaan Agama Islam, 2003

Tim Dosen PAI, Bunga Rampai Penelitian dalam Pendidikan Agama Islam, Yogyakarta: Deepublish, 2016
Zuhriy, M. Syaifuddien, "Budaya Pesantren dan Pendidikan Karakter pada Pondok Pesantren Salaf", Jurnal Walisongo, UIN SUKA Yogyakarta Vol. 19, No. 2, November 2011 